\title{
The Syntax Features of the African American English. In Georgia Doyle Johnson's Frederick Douglas And Loraine Hansberry's $A$ Raisin in the Sun
}

\author{
Nizamuddin Sadiq \\ Islamic University of Indonesia
}

\begin{abstract}
Syntax reflects features of a language. One of the American African English features in syntax can be seen in Georgia Doyle Johnson's Frederick Douglas and Loraine Hansberry's $A$ Raisin in the Sun. As it is considered non-standard dialect, the American African English syntax is assumed to have its own characteristic different from the standard American English.

This paper is descriptive linguistics rather than a stylistic study as it does not focus on literary style. The data taken was classified into linguistic elements and was tested to the theories of informal English in general; African American English in particular and Standard American English rules of pronunciation. The research findings were summarized and discussed to conclude the research.
\end{abstract}

The result of the research demonstrates that African American English, a variant of informal English, is different from the rules of Standard American English. In terms of syntax, the African American English style if it is seen from viewpoint of grammar function contradicts with features of Standard English: clarity, brevity and fluency. The rules of clarity are broken by the presence of ellipses, clippings, copulas and tenses; brevity by the presence of unnecessary repetition and additions; and fluency by the presence of combinations of assimilation and clipping. African American English speakers employ polite expressions. The research revealed that polite expressions when greeting people, using please when asking for permission and using titles to show respect is done, particularly with elders. Furthermore, when the speaker is angry, she/he uses a complete name for emphasis.

Key words: syntax, clarity, brevity, grammar function, the African American English 


\section{A.Introduction}

As African American English is an ethnic dialect of English that is considered non-standard, it can also be called a vernacular dialect and is considered to be the most conspicuous and prominent example of non-standard dialect. African American English is a bona fide language system with its own rules of pronunciation, syntax-and lexicon. The grammatical structure (syntax) of African American English is relatively rigid and fixed and is clearly pattemed and systematic, not random and haphazard. Therefore, the style of African American English can be identified and studied.

African American English is a type of informal English style that is spoken by most working and lower-class African Americans every day. Its linguistic features are a reflection of the people themselves. Thus, the elements of this particular type of morpho-syntax are the focus of this research.

The focus of the research was Georgia Doyle Johnson's Frederick Douglas and Lorraine Hansberry's $A$ Raisin in the Sun. The former is an African American history play taken from Plays for Reading: Using Drama in EFL, a compilation of plays edited by Thomas Kral published by United States Information Agency in 1997, page 139-150. The latter is also an African American history drama, published in 1958, page 23-151. The two plays are Dramas Theater containing conversations among characters in the African American society.

\section{B.Discussion}

Linguistic elements play an important role in language. By comprehending these features, a language structure can be identified. This section will describe syntax.

\section{B.1 Combination of Assimilation and Clipping}

The research of the two plays revealed very few examples of morphology as applied to Standard American English. Instead, most words in African American English are a combination of assimilation and-clipping, as seen in the examples below:

(Drawingly) I ain't hungry. (Slouches down lower on chair) I wanta sleep. (FD);

Sure! But what you reckin' is keeping Bud so late; he knows Sadday night 
is lesson night: (Takes cake and tastes it) Good! (FD);

Mebbe four more, an' then, little honey. (He snaps his finger exultantly) I'm a-goin'... (FD);

Oh, Bud, I want you to do somethin' fur me (He doesn't answer). Hearme, lissen, I want you to lemme have yore pass fur a little while. Lemme see it. Where is it, Bud? (FD);

Gaaaleee! I don't ask her, she just gimme it sometimes (ARITS);

Oh, Fred, you so good, teachin' me an' Bud to read an' figger an'ev'rything. Whus more, Bud likes you an' you know he don't like nobody much he jes' loved Ma and that's all! (FD);

Bennie, why you always gotta be pickin; on your brother? Can't you be a little sweeter sometimes? (ARITS);

Wamme to talk with de sperrits in yore leaves? (FD, 148)!

Wanna, Sadday, mebbe, lemme, gimme, whus more, gotta and wamme show that these words are combination of assimilation and clipping. The word wanna is from want to; Sadday from Saturday; mebbe from may be; lemme from let me; gimme from give me; whus more from what is more; gotta from got to; and wamme from want me.

\section{B.2 Ellipsis}

African American English contains many instances of ellipses, which can be divided into three categories: simple, compound and complex sentence. Most ellipses found in the research appeared in simple sentences, and they can be described in five categories.

\section{- B.2.1 Ellipsis of subject}

According to Quirk and Greenbaum (1985:253), in informal situations the subjects can be omitted. Leech and Svartvik (1979:117) agree, adding that omissions usually-occur with words that carry little meaning such as pronoun subject. The omission of the subject (symbolized by words in parentheses), caused by the speed of the speaker in uttering the sentence, is evidenced by the examples below. However, since it is not a formal language, the absence of subjects in imperative sentences is not considered an ellipsis of the subject.

(It) Looks chilly out this morning (ARITS);

I'm serious. (You) Just pack up and leave. (You) Go on away and enjoy yourself some (ARITS); 
Yes, a fine man. (He) Just couldn't never catch up with his dreams; that's all (ARITS);

(You) Mind your own business (ARITS, 48);

\section{B.2.2 Ellipsis of subject + verb.}

In simple sentence discourses, it is common to find ellipsis of subject + verb in order to avoid repeating some of the elements, as seen in the following:

Travis : Where?

Mama : (She went) To tend her business (ARITS)

Beneatha : Mama, where did Ruth go?

Mama : (She went) To the doctor, I think (ARITS)

Mama: Where did you go today, girl?

Ruth : (I went) To the doctor (ARITS)

Mama: You got a job, a nice wife, a fine boy and-

Walter : $\left(\boldsymbol{I}_{\text {got }}\right.$. A job. Mama, a job? (ARITS)

Walter: What kind of Negroes?

Beneatha : (I mean) Old Fashioned Negroes.

Walter: Sonson, what do you want to be when you grow up?

Travis : ( $I$ want to be) $A$ bus driver (ARITS)

\section{B.2.3 Ellipsis of subject + verb + object.}

The ellipsis of subject + verb + object omits whole elements of the sentence. For example in (I'll have) some coffee (for my breakfast) (ARITS) almost all elements are ellipse, such as the subject $I \prime l$, the verb have, the preposition for and the object complement my breakfast. Other examples can be seen below:

Ruth : You get to New York a lot?

George : (I get to New York) Few times a year (ARITS)

Beneatha : Why are you angry, George?

George : ( am angry) Because this is stupid! (ARITS)

Beneatha : My brother isn't here just now. Is it business?

Mama : Yes...well, (it is) of a sort (of business) (ARITS).

The examples above are in the positive form. Ellipsis of subject + verb + object also occurs in an interrogative form.

Beneatha : There's really only one way to get rid them, Mama.

Mama : How (do you get rid them)? (ARITS). 
In addition, there are many examples found that the object is ellipse. Examples are:

Are you really (glad)? (ARITS);

Yes, there is (something the matter with me) (ARITS);

Is he (a fool), Baby? (ARITS);

Is he(here)? (ARITS);

Oh, I probably will (get married)... (ARITS).

\section{B.2.4 Ellipsis of subject + operator}

Also occurring frequently is ellipsis of the first person $+b e, i t+i s$, or first person pronoun followed by an auxiliary verb other than be such as will and have:

(My robe is) In the cleaners (ARITS);

Yes'm (I have) Finished early (ARITS);

(He is) Asagai Joseph Asagai (ARITS)

(It is) Ten twenty (ARITS);

How should I know (They are) out hunting or something (ARITS)

(I am) Fine, (I am) Fine. How are you? Oh, $(\mathrm{I}$ am) a little tired (ARITS);

(I am going) To become queen of the Nile (ARITS):

(I am welcoming) The men back to the village (ARITS).

In the declarative sentences above, the subject should appear in the initial position followed by an operator. However, interrogative sentences should begin with a subject complement or an adjunct. In African American English, these are ellipse as follows:

'Are you) Tired of everything? (ARITS);

(Will she) Get over it? (ARITS);

(Do I) Understand what, baby? (ARITS).

When there is a preposition in a sentence, subject + operator + preposition are frequently ellipse. For example:

(I am going with) George Murchison again (ARITS);

But (it is about) liquor, honey(ARITS);

(It is about) race, race, race...(ARITS).

\section{. B.2.5 Ellipsis of operator}

In interrogative sentences, it is common to omit the operator positioned initially. For instance: 
(Have) You had breakfast? (ARTTS);

(Is) Something wrong with that? (ARITS);

(Do) You think Grandma would have it? (ARITS).

Occasionally, not only the operator is omitted but also the subject and the verb. For example:

(Do you need) Fifty cents? (ARITS);

Mama, (do I have) a job? (ARITS);

(Do you like talking) About what? (ARITS);

(You want to be) $A$ what? (ARITS).

B.2.6 Ellipsis of verb, object and adverb. .

For example:

Walter: What is it he wants to do?

Ruth: Go carry groceries after school at the supermarket.

Walter : Well let him go (ARITS).

Ruth's answer should be He wants to carry groceries after school at the supermarket. Ruth's original answer omits the subject $\boldsymbol{H} e$, and the verb wants to.

Walter's response Well let him go omits many more elements. The sentence omits carry groceries after school at the supermarket.

Fewer instances of ellipsis of the subject in compound sentences occur, possibly because there are fewer compound sentences, making it difficult to determine if ellipses in compound sentences are stable features of African American English in general.

\section{B.2.7 Ellipsis of subject}

Only two instances were found, as follows:

(You) Get on out of here or you going to be late (ARITS);

If you a son of mine, (you) tell her! (ARITS).

\section{B.2.8 Ellipsis of operator}

There were two examples found:

Get on out of here or you (are) going to be late (ARITS);

You think you (are) a woman, Bennie but you (are) still a little girl-

(ARITS). 


\section{B.2.9 Ellipsis of subordinator, subject and operator}

In the example: Well, being a colored woman, I guess I can't help myself none (ARITS) the subordinator since, the subject $I$ and the operator $a \dot{m}$ are ellipse. A complete senterice would have been Since I am a colored woman, Iguess I cain't help myself none.

In the following example the subordinator and operator are ellipse: Here I am a giant (who is) surrounded by ants! (ARITS).

\section{B.2.10 Preposition ellipsis}

There was one example of an ellipse preposition:

(On) Monday morning I want you to take this money and take three thousand dollars and put in a savings account for Beneatha's medical schooling (ARITS).

In the following example almost all of the elements of the sentence have been ellipsed, including the independent clause and the subject $I$ and the operator will and the verb work in the dependent clause:

Travis : You didn't work in no office, Daddy

Walter: No, (I didn't work in no office today) but after tonight ( will work) (ARITS).

Fewer ellipses in complex sentences were found than ellipses in compound sentences. In general, ellipses in complex sentences can be described in four categories.

\section{B.2.11 Ellipsis of operator}

Examples are:

Who is that you (are) inviting over here with this house looking like this? (ARITS);

If you (are) through eating, you can get over there and make up your bed (ARITS).

\section{B.2.12 Ellipsis of subordinator and operator}

In the sentences below the subordinator that and what and operator have and is are ellipse:

I say (that) I (have) been wrong, sonThat (what) I been doing to you is what the rest of the world (is) doing to you (ARITS). 
B.2.13 Ellipsis of subject and operator, as seen in the example below:

(I have) Been thinking that we maybe could meet the notes on a little old two-story somewhere, with a yard where Travis could play in the summertime, if we use part of the insurance for a down payment and everybody kind of pitch in (ARITS).

The subject $I$ and the operator have are omitted.

B.2.14 Ellipsis of dependent clause, for instance:

Mama : Sonhow come you talk so much bout money?

Walter : (I talk so much 'bout money) Because it is life, Mama! (ARITS).

\section{B.3 Proverbs or Idiomatic Expressions}

African American English employs many idiomatic expressions, as seen in the sampling below:

Drink hisself to death (ARITS);

To climb up in the chariot (ARITS);

Grow thin and old (ARITS);

Beat a man to death (ARITS):

Sticks and stones may break my bones (ARITS);

The way crackers crumble (ARITS);

When a cat take off with your money he don't leave you no road maps

(ARITS);

That money is made out of my father's flesh (ARITS);

Meet the notes on a little old two-story (ARITS); .

Empty as Jacob's kettle (ARITS);

Smell iron on the face of the earth (ARITS);

Afraid of no crackers (ARITS).

\section{B.4 The Use of or Something}

African American English uses or something to indicate another choice or thought, as seen in the examples below:

Take a taxicab to school or something (ARITS);

You might be calling me little idiot or something (ARITS);

How should I know out hunting or something (ARITS);

She looks like she got burnt legs or something (ARITS); 
May be may be he's been callin' you at home tryin' to tell you whàt happened or something (ARITS).

\section{B.5 The Use of and All (That) .}

According to Quirk et al (1985:260) all can be used as informal intensifying adverb, as seen in the following from $A$ Raisin in the Sun:

I would love to hear all about your country (ARITS);

You're getting me all mixed up (ARITS).

However, another use of all was found, sometimes adding and or that in place of etc, for example:

No...house cleaning and all that (ARITS);

I mean; do they wear clothes and all that (ARITS);

You wear it well...very well...mutilated hair and all (ARITS).

\section{B.6 The Use of Go}

According to Thompson and Martinet (1986:241) go can be followed by the participle verbs of physical activities. For example, they are going riding/skating/skiing or I'm going shopping this.afternoon. Whereas, Azhar (1993:250) states that go is followed by a gerund in certain idiomatic expressions about activities. For example, did you go shopping yesterday?

The use of go in African American English in A Raisin in the Sun does not follow either definition, as go is not followed by the verb ending [-ing] or a gerund. The following are examples:

go carry, go be a nurse, go get mine, go do something, go ahead, go selling, go on out, go off.

\section{B.7 Double or Maltiple Negations}

Double or multiple negations are frequently used. For example:

Oh, no, he ain't going to bed to be getting up no earlier no such thing! (ARITS);

I ain't specting nobody (FD);

Slaves 'round here can't read nothing (FD);

Well whether they drinks it or not ain't none of my. business (ARITS);

You ain't never done nothing with all the camera equipment (ARITS). 


\section{B.8 Interjections}

Interjections are often used in spoken language, and in African American English many are unique:

Look a-here! (FD), Whoopee (ARITS), Ahhhhhhhhh (ARITS), Whew! (ARITS), Pssst (ARITS), Good Lawd! (FD), Thankee! (FD), Aw Gaaalee! (ARITS), Gaaaleee! (ARITS).

Additionally, the interjection hush in $\dot{A}$ Raisin in the Sun emerges frequently. The following are examples:

Ruth to Travis : Hush up now and just eat! (ARITS)

Mama to Ruth : Hush, Ruth! (ARITS)

\section{B.9 Syntax Deviations}

African American English frequently breaks syntax rules. The first, [s] is often added to verbs for all subjects (hypercorrections). In Standard American English, in the case of the subject-verb agreement, the addition of an [s] to verbs in the simple present tense is only employed for the third person singular subject. For first and second plural subjects, the verbs do not have an additional [s]. In African American English this rule is broken. For all subjects, [s] is added to the verb. For instance:

I hopes to God you ain't going to get up here first thing this morning (ARITS);

You looks right peaked (ARITS);

They frightens me, Ruth (ARITS);

How we gets to the place where we scared to talk softness to each other? (ARITS):

Similarly, [s] is not added to many verbs in the simple present tense, when according to the rules of Standard American English, it should be. Examples are:

Teacher say * we have to (ARITS);

She think* more of you (ARITS);

- Man say* to his woman: Eat your egg (ARITS);

Everybody say* it's got to do with them bombs and things they keep setting off (ARITS);

He always know* how to have a good time (ARITS). 
In negative forms, the subject-verb agreement rule is also broken. The third person singular of present subject (he/she/it) must be followed by does + not.

In African American English, the third person singular of present subject (he/she/it) is followed by $d o+$ not, as follows:

No, he don't half try at all cause he knows you goin' to come along behind

him and fix everything (ARITS);

It don't sound nice for a young girl to say things like that you wasn't brought up that way (ARITS);

Honey'...life don't have to' be like this (ARITS);

Getting so she don't have much to say: to nobody (ARITS).

The second, instead of using the pronoun $I$, many African American English sentences use the pronoun object me, especially when another subject noun is employed. Examples are:

Me just a poor slave (ARITS);

Me and Ruth done made some sacrifices for you (ARITS);

I remember just as well the day me and Big Walter moved in here (ARITS);

Me and your father went to trouble to get you and Brother to church every Stunday (ARITS);

Me and you ought to sit down and talk sometimes, man (ARITS);

Me and Beneatha still to have share our room (ARITS).

The third, in African American English the verb form was is used for the second singular and pluraI, wherc-in Standard American English grammar, the verb form was is used for the third singular person (he/she/it) in the past tense. The research found that was is used for the second singular you-and the plural we and for sentences including more than one person subject. Examples of you + was are:

Well, what was you doin' all that yelling for...(ARITS);

...Honey, I knew you was odd (ARITS);

You ain't got the pride you was bom with! (ARITS).

Examples of using we + was are:

We was goin'to set away, little by little... (ARITS);

... We couldn't of gone on like we was today (ARITS);

In my time we was worried about not being lynched... (ARITS). 
Examples of using was for more than one person are:

What was you and your brother fussing 'bout this morning? (ARITS);

Bout what me and Willy Harris was talking about last night (ARITS);

He and Bennie was at it again (ARITS).

The fourth, a subject pronoun replaces a possessive pronoun in African American English. For example:

My children and they tempers (ARITS);

. They don't thing nothing of patching up they suitcase (ARITS).

The subject pronoun they should be replaced by the possessive their.

The fifth, in question patterns do-is omitted. Some examples.are:

What *you mean out? (ARITS);

What kind of egg * you want?-(ARITS);

What * I look like wandering 'round Europe by my self! (ARITS);

* you think Grandma would have it? (ARITS);

*you hear me? (ARITS);

* you mean that liquor store that Willy Harris want him to invest in? (ARITS).

The asterisk $\left[{ }^{*}\right]$ shows the position of do that is missing.

The sixth, in questions, how come replaces why. According to Quirk et al (1985:840), how come is used in African American English speech to introduce reason questions. The examples are:

How come you always try to be so pleasant? (ARITS);

How come you done taken it in your mind to learn to play the guitar?

(ARITS);

Son how come you talk so much 'bout money? (ARITS).

The seventh, the subject- verb agreement is used inappropriately. Examples are:

Oh, she just have a fit... (ARITS);

But Travis have one of his own (ARITS).

The use of have in these sentences is not appropriate as the subjects are the singular she and Travis. The appropriate verb is has.

The eighth, reflexive pronouns for third person $h e$ is combined with the possessive pronoun his. Therefore, the reflexive pronoun himself replaces hisself. Examples are: 
Oh, that man grieved hisself! (ARITS):

I guess that's how that man finally worked hisself to death like he done (ARITS);

Why don't you all never let the child explain hisself (ARITS);

And can't believe in hisself...(ARITS).

\section{B.10 Predications without Copulas}

A copula is the verb form be when it is used to join the subject to its complement. According to Holmes (2001:177) African American English speakers of lower socio-economic groups regularly omit the copula verb be in its predication, as in the examples below:

He ${ }^{*}$ just going to have to start getting up earlier ( ${ }^{*}$ is) (ARITS);

You * a horrible-looking chick at this hour (* are) (ARITS);

- Gaalee, Grandma you * rich (* are) (ARITS);

Your wife say she * going to destroy your child (* is) (ARITS).

If there is a copula in the predication, the use of the copula is wrong, for example, we both was around eight. The copula was is not correct because the subject we is - plural. The copula was should be replaced by were. Other examples are:

We was going backward 'stead forward (was should be were) (ARITS);

There wasn't many people in the street (wasn't should be weren't)

$(A R I T S)$;

He and Bennie was at it again (was should be were) (ARITS).

In interrogative sentences, the copula is also missing. Some examples of interrcgative sentences without copulas are:

Check coming today? (* is) (ARITS);

* somethin' the matter with you this morning? (*Is) (ARITS);

* you aimin' to iron all them things? Leave some for me (*Are) (ARITS);

Who * you goin' out with tomorrow night? (*are) (ARITS).

\section{B.11 Repetitions}

There are several types of repetition found in the syntax of African American English. The first, word repetitions occur in almost every sentence of the two plays.

According to Quirk et al (1975:1416) reinforcement is a feature of colloquial style whereby an item is repeated for the purpose of emphasis, focus or- 
thematic arrangement. Its simplest form is merely a reiteration of a word or phrase. The examples of word repetitions below denote emphasis:

Honey, you jes' like a rock in a weary land..... weary land..... weary land! $(F D)$;

I never saw it I never saw my own Ma but one time in my whole life (FD);

In the mornin'...in the mornin'...I got to do something before mornin' (FD):

I don't know...I don't know but I got to get away...got to! (FD)

I know...I know...I'll make some tea! (FD);

and I am going to sit... and sit... and sit in that hot water (ARITS);

I seen him grow thin and old before he was forty...working and working and working like somebody's horse (ARITS).

The second, repetition of the subject and object is encountered often in African American English using them to replace those, such as:

...where them white boys are sitting back and talking about things...(ARITS);

Them houses they put up for colored in them areas (ARITS).

Examples of repetition of the object are:

All you can say is eat them eggs and go to work (ARITS);

Everybody say it's got to do with them bombs (ARITS);

Ijust sat in the car and looked at them big chimneys for hours (ARITS);

You can just sit there and drink and listen to them three men play (ARITS).

The third, in spoken language, a preference for coordination another form of repetition rather than subordination becomes one of its features. In the speech below the coordinator and occurs eight times in one sentence:

All you have to do is just sit down with her when you drinking your coffee one moming and talking 'bout things like you do andyou just sip your coffee, see, and say easy like that you been thinking 'bout that deal Walter Lee is so interested in, 'bout the store and all, and sip some more coffee, like what you saying ain't really that important to youand the next thing you-know, she be listening good and asking you questions and when you come hereI can tell her the details (ARITS). 
The fourth; in another interesting type of repetition, African American English employs more words than are actually needed to complete a sentence. For instance in the sentence, Could I maybe go carry some groceries...? (ARITS), maybe and go are unnecessary.

Other examples are:

Seems like God didn't see fit to give the black man nothing but dreams (ARITS);

Don't ask him a whole lot of ignorant questions about Africa (ARITS); Younger just be plain mad if... (ARITS);

Mama, you didn't go do something with that insurance money, something crazy? (ARITS);

I am only teasing you because you are so very serious about these things (ARITS);

... for the last three years to help put clashes on her back? (ARITS);

Brother still worrying hisself sick about that money (ARITS).

\section{B.12 The Use of Signposts}

According to Leech and Svartvik; one can indicate structure by using such signposts as firstly, secondly, finally, to conclude, and to summarize. In African American English, these formal signposts are not found. Instead, new points are introduced by such expressions as those found below:

So (ARITS), anyway (ARITS), listen, man (ARITS), all I can say is (ARITS), as for myself (ARITS), one thing (ARITS), I bet (ARITS), I guess (ARITS), I spec (ARITS), If it means (ARITS), as I say (ARITS), I don't say

B.13 Incorrect Tenses

(ARITS), that's what I'm trying to say (ARITS), as I was saying (ARITS).

The incorrect use of tenses is typical in African American English. The first, when speakers indicate remote past through verb structure, they notably use done, as in the examples below:

You done found it in some other house (ARITS);

Girl, you done lost your riatural mind? (ARITS);

We done thought about all that Miss Johnson (ARITS). 
Furthermore, when the past perfect tense is employed, African American English speakers notably use been instead of have been, as seen in the examples below:

I been married eleven years (ARITS);

...You been cut up or something when you tell 'em you sick (ARITS);

The past few years I been watching it happen to you (ARITS);

Where you been, Walter Lee? (ARITS);

What you been doing for these three days, son? (ARITS);

But ain't never been wrong 'bout a woman neither (ARITS).

The second, to indicate habitual action through verb.structure, be is used incorrectly according to the syntax of Standard American English.

According to

Landrum-Brown, the use of be derives from an-aspectual verb system that is also

found in many African languages. Its use conveys the speaker's meaning with

reference to qualitative character and distribution of an action over time.

Examples of this kind are:

She be listening good (ARITS);

That be ten thousand each (ARITS);

What time you be home from school today? (ARITS);

She be all right (ARITS);

I be by myselffor a while (ARITS);

I be down directly (ARITS).

The third, to indicate past action, speakers use done in place of did. For example:

Just like he done every morning for the last umpteen years (ARITS);

Like you done this morning (ARITS);

You think I done the right thing (ARITS).

The fourth, when the speakers use tenses, they do not use them appropriately, for instance:

I seen one marching out of there like Napoleon yesterday (ARITS);

We known it was coming for months (ARITS).

The verbs seen and known are inappropriate for the use of past tense and should be replaced by saw and knew. 


\section{B.14 Inappropriate Sentence Patterns}

Several sentence styles in African American English do not follow Standard American English sentence patterns. The first, the use of sub-clauses is typical beginning with: but and 'cause forming dependent clauses rather than complete sentences, as shown in the following examples:

But he gives me to Marse Tom (ARITS):

'Cause we don't have it (ARITS).

The second, past modals (should/would/could) are preceded by have + participle in Standard American English. In African American English have is replaced by of, for example:

Mama, you should of seen the rat (ARITS);

She could of done gone into the banking business! (ARITS);

We couldn't of gone like we was today (ARITS);

Somebody would of thought my children done all but...(ARITS).

The fourth, in sentences which imply result, the if clause is omitted. For example: Eat your eggs, they gonna be cold (ARITS). This sentence should be If you do not eat your eggs, they gonna be cold. If you do not is omitted and when it is omitted, the sentence needs a conjunction such as or, e.g. Eat your eggs or they gonna be cold. Another example is: Get on out Lee or you going to be late (ARITS).

\section{B.15The High Frequency of Using Thing}

According to Leech and Svartvik (1985:786) the use of thing is an informal emotive expression unique to African American English. In A Raisin in the Sun, thing is used frequently, as shown in the examples below:

The thing I want to talk about (ARITS);

First thing a man ought to learn in life is ...(ARITS);

Talking about things like you do (ARITS);

It's just that people ask such crazy things (ARITS);

Lord, that's a pretty thing jus went out here! (ARITS).

\section{B.16The Use of Got}

In African American English, the first word of have got to is completely elided, so that the pronunciation of the whole idiom is reduced to [got?], thus making it resemble a single auxiliary. This reduction is represented in dialogue by the omission of ' $v e$ and sometimes by the non-standard spelling gotta. For instance, 
(SLIAH)

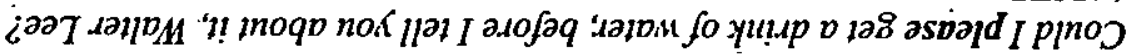

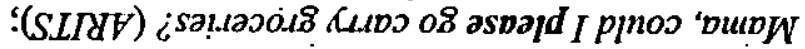

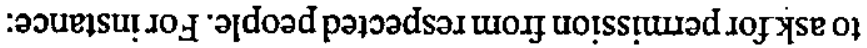

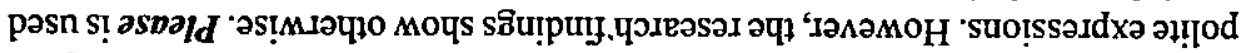

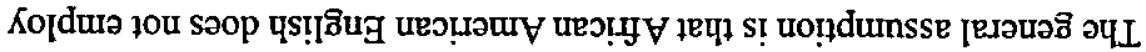

suonssaddxg an! ${ }^{\circ} \mathrm{d}^{\circ} \mathrm{g}$

(SIIVV) ysauf os l, uaram noif/I

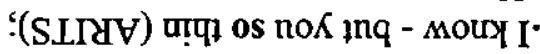
؛(SLIVE) posvold os $t_{i}$

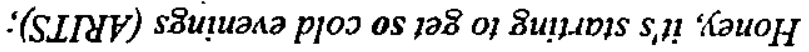

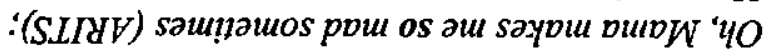

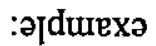

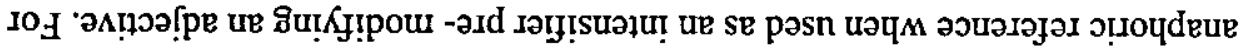

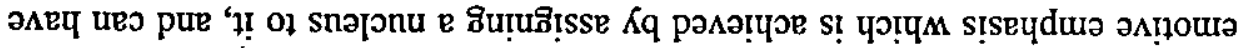

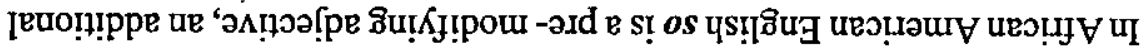

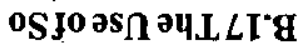

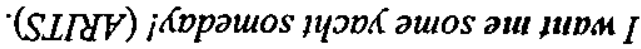
:(SLIYV) $\eta$ ? ау

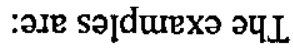

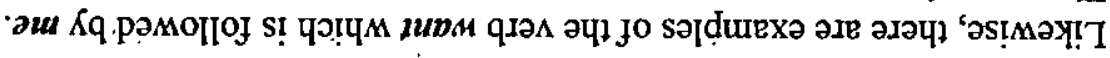

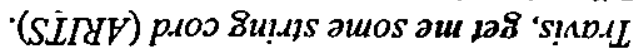
(SLIYV) spop! autos aut $1088_{I}$ 'uvW ؛(SLISH) unatp p ou $108 I$

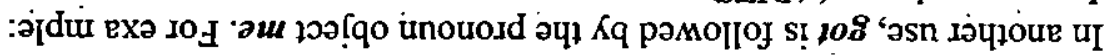

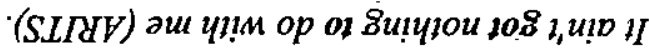
$:($ SIIAB) ut o8 ol 108 I

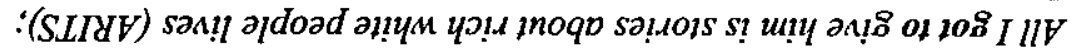

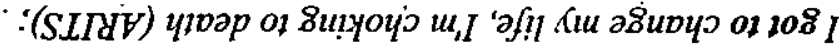
‘(SLIAV) iKqpq 'pl.10m a.lay s!ly fo ploy aypl o1 108 I

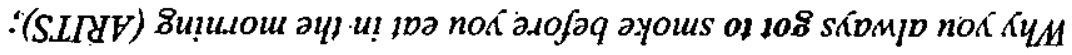
:мoją paquiosap are sajduexo

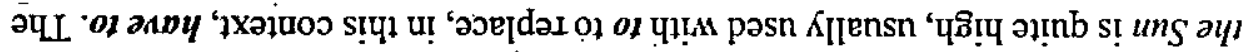

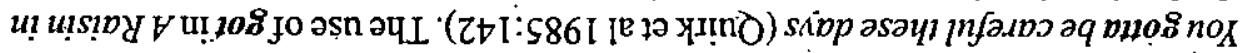


In many sentences, please is used as an imperative. For example:.

Please, stop it! (ARITS);

Honey, please go iowork! (ARITS);

Darling please handle it so we can sit in it again! (ARITS);

Please forgive me for coming at such an outrageous hour on a Sunday (ARITS).

Additionally, polite greetings are also seen in African American English, as seen below:

George: Ohhello, Mrs. Younger.

Mama : Hello, George, how you feeling?

George: Finefine, how are you?

Mama: Oh, alittle tired. You know them steps can get you after

a day's work. You all have a nice time tonight?

George: Yesa fine time. A fine time.

Mama: Well, goodnight.

George: Goodnight.

Mama: Ohhello there, Johnson.

Johnson : Hello there, youself! H'you this evening, Ruth?

Ruth: Fine, Mis'Johnson, h'you?

In another example, the speaker meets an elder person for the first time and greets the person formally, as seen in the following short conversation.

Beneatha: OhMamathis is Mr. Asagai

Mama: How do you do?

Asagai : How do you do, Mrs. Younger. Please forgive me for . coming at such an outrageous hour on a Saturday.

Titles such as Miss, Mŕs., Mr., Aunt or Uncle (even for non-relative) are used to show respect, as follows:

Ruth to Mama: You know what you should do, Miss Lena?

Bobo to Ruth: Yesh'you, Miss Ruth?

\section{B:19 Inappropriate Plural Usages}

Plurals are used inappropriately in $A$ Raisin in the. Sun. Some can be followed by a plural noun (such as a length of string) or a singular noun (such as yacht): 
Travis, get mè some string cord (ARITS);

I want me some yacht someday! (ARITS).

\section{B.20 Amplificatory Phrases}

In Standard American English, an amplificatory phrase may be informally added after the completion of a clause structure which contains a co-referential pronoun (Quirk et al, 1985:1417). In African American English, the amplificatory phrase is added directly after the pronoun. For example:

Bennie, honey, it's too drafty to be sitting 'round half-dressed. My creature, young creature of the worldMy dear, young creature of the $\mathrm{New}$, World Ido not mean ocean the city Imean across ocean. Home to Africa. (ARITS):

He was a good man, Mr. Younger (ARITS);

And then, Lord, when I lost that baby little candle Ialmost thought I was going to lose Big Walter, too (ARITS).

\section{Conclusion}

The results of the research demonstrate that African American English, a variant of informal English, breaks the rules of Standard American English. In terms of syntax, the African American English style if it is seen from viewpoint of grammar function contradicts with the features of Standard English: clarity, brevity and fluency. The rules of clarity are broken by the presence of ellipses, clippings, copulas and tenses; brevity by the presence of-unnecessary repetition and additions; and fluency by the presence of combinations of assimilation and clipping. Several non-standard grammar rules as the African American English are: a) ellipses; b) idiomatic expressions; c) or something; d) and all (that); and e). go. One of very common features of African American English is multiple negations. It reveals that the African American English employs what the so-called hypercorrection.

\section{Bibliography}

African American Vernacular English. Retrieved From World Wide Web: http://www.biocrawler.com/encyclopedia/. Date of access: Nov 12, 2006 
Azhar; B. S. (1993) Fundamentals of English Grammar. Edisi Inggris-Indoniesia. . 2nd Edition. Jakarta: Bina Rupa Aksara

Baugh, A. C., and Cable, T. (1978) A History of English Language. Englewood Cliffs: Prentice-Hall Inc.

Carter, R. (1999) Standard English: The Widening Debates in Bex, T and Watts, R.J. (eds.), "Standard Grammar, Spoken Grammar: Some .Educational Implication. "London: Routledge. Pp. 149-165

Chaika, E. (1982) Language the Social Mirror. Massachusetts: Newbury House Publishers, Inc.

Collins, B., and Mees, I. M., (2003) Practical Phonetics and Phonology: $A$ Resoturce Book for Students. London and New York: Routledge

Cruse, D.A. (1986) Lexical Semantics. Cambridge: Cambridge University Press

Crystal, D. (1995) The Cambridge Encyclopedia of the English Language. Cambridge: Cambridge University Press

Hansberry, L. (1958) A Raisin in the Sun. New York: Vintage Books

Holmes, J. (2001) An Introduction to Sociolinguistics. Harlow: Pearson Educational Limited

Jackson, H. (1982) Analysing English. An Introduction to Descriptive Linguistics.2nd Edition. Pergamon Press Limited.

Johnson, G. D., Frederick Douglas in Kral (1997) Plays for Reading: Using Drama in EFL. Washington: United State Information Agency Laundrum-Brown, J. Black English. Retrieved From World Wide Web: http:/geoffbarton.co.uk.files/. Date of Access: March 15, 2006 ,

Leech, G. N., and Svartvik, J. (1975) A Communicative Grammar of English. 2nd Edition. London and New York: Longman

McManis, C (ed) (1987) Language Files. Materials for an Introduction to Language. Ohio: Advocate Publishing Group

Poedjosoedarmo, S. (1976) RagamTutur Ringkas Bahasa Indonesia. Pp. 27-35. (1979) Tingkat Tutur Bahasa Jawa. Jakarta: Pusbinbangsa (1979) Kode Tutur Masyarakat Jawa. Yogyakarta: UGM 
Quirk, R. Greenbaum, S., Leech, 'G., and Svartvik, J. (1985) A Comprehensive Grammar of the English Language. Volumes 1 and 2. London and New York: Longman

Quirk, R: and Greenbaum (1973) A University Grammar of English. England: Longman

Shepperd, V. (1994) Literature About Language. London: Routledge

Sidnel, J. African American Vernacular English (Ebonics). Retrieved From World Wide Web: http://www.une.edu.ourlangnet.aave.htm. Date of access: Nov 12,2006

Stewart, M. M. (ed) (1978) Business English and Communications. New York: McGraw Hill Book Company

Thompson, A. J., and Martinent, V. (1986) A Practical English Grammar. 4th Edition. Oxford: Oxford University Press

Trudgill, P. (1999) Standard English: The Widening Debates in Bex, T and Watts, R.J. (eds.), "Standard English: What It Isn't?" London: Routledge.

Wardhaugh, R. (1992) An Introduction to Sociolinguistics. Oxford and Cambridge: Blackwell

Wolfram, W. and Christian, D. (1984) Dialect and Education. Issues and Answers. New Jersey: Prentice Hall Regents 